\title{
Kuraklık Riski Altındaki Havzalarda Gölet Haznelerinin Tasarımı: Seyhan Havzası'nda Bir Uygulama
}

\author{
Ali Demir KESKİNER ${ }^{1}$ \\ Mahmut ÇETÍN ${ }^{2}$ \\ Mehmet ŞIMSŞEK ${ }^{3}$ \\ Sabri AKIN ${ }^{4}$
}

ÖZ

Gölet kapasitelerinin tasarımında, M. Turc yöntemi ile hesaplanan \%50, \%80 ve \%90 olasılıklı havza su verimleri kullanılmaktadır. Bu çalışmada, kuraklığa eğilimli havzalarda gölet hazne tasarımları için uygun olasılık düzeyinin belirlenmesi amaçlanmıştır. Meteoroloji gözlem istasyonlarının yıllık toplam yağış serilerine frekans analizi uygulanarak her istasyon için $\% 50, \% 80$ ve $\% 90$ olasılıklı beklenen yağışlar elde edilmiştir. İstasyonlara ait \%50 olasılıklı yağış değerleri ile Normalin Yüzdesi İndeksi (NYİ) kuraklık sınıflarına karşılık gelen $\% 65, \% 75$ ve \%85 kuraklık eşik yağış değerleri hesaplanmıştır. Bu değerler, Coğrafi Bilgi Sistemi $(C B S)$ ortamında Ordinary Cokriging yöntemi ile haritalanarak M. Turc yöntemine göre farklı olasılıklarda ve eşik değerlerde yüzey akış haritaları oluşturulmuştur. Yüzey(sel) akışların, hipsometrik eğrileri çizilmiştir. \%80 ve \%90 olasılıkla beklenen akımların hipsometrik eğrileri "Hafif" ve "Orta Şiddette” kuraklık sınıfına karşılık gelen eşik yağış akımlarını, \%50 olasılıklı akımlar ise "Normal ve Üzeri-Risk Yok" kuraklık sınıfı eşik üstü akımları temsil etmiştir. Seyhan Havzası'nda gölet hazne tasarımlarında, \%50 olasılıklı havza su verimlerinin kullanılması uygun bulunmamıştır. Maliyet azaltımı için, \%80 veya \%90 olasılıklı yüzey akışların kullanılması önerilmiştir.

Anahtar Kelimeler: Normalin Yüzdesi İndeksi (NYİ), kuraklık, CBS, M. Turc yüzey akışı.

\footnotetext{
Not: Bu yazı

- Yayın Kurulu'na 31 Aralık 2018 günü ulaşmıştır. 23 Aralık 2019 günü yayımlanmak üzere kabul edilmiştir.

- 30 Kasım 2020 gününe kadar tartışmaya açıktır.

- https://doi.org/10.18400/tekderg.505584

1 Harran Üniversitesi, Tarımsal Yapılar ve Sulama Bölümü, Şanlıurfa - adkeskiner@harran.edu.tr https://orcid.org/0000-0002-7930-9363

2 Çukurova Üniversitesi, Tarımsal Yapılar ve Sulama Bölümü, Adana - mcet64@cu.edu.tr https://orcid.org/0000-0001-5751-0958

3 Harran Üniversitesi, Tarımsal Yapılar ve Sulama Bölümü, Şanlıurfa- mehmetsimsek@harran.edu.tr https://orcid.org/0000-0002-9552-1743

4 Harran Üniversitesi, Tarımsal Yapılar ve Sulama Bölümü, Şanlıurfa - sabriakin@harran.edu.tr https://orcid.org/0000-0002-9196-3157
} 


\section{ABSTRACT \\ Design of Small Earthen Dam Reservoirs Lying in Drought-Prone Areas: An Application to the Seyhan River Basin}

Catchment water yields, calculated by $M$. Turc technique, having probability levels of $50 \%$, $80 \%$ and $90 \%$ are used for the design of reservoir capacity of small earthen dams. This study aims to figure out the suitable probability levels to be used for the design of reservoirs of small earthen dams lying in drought-prone areas. After having performed frequency analysis technique on the yearly total precipitation series of each meteorological station, precipitations values with $50 \%, 80 \%$ and $90 \%$ probability levels were estimated for each meteorological station. By using precipitations at $50 \%$ probability level, precipitation threshold values corresponding to Percent of Normal Precipitation Index (PNI) drought categories of $65 \%$, $75 \%$ and $85 \%$ were calculated for each station. These precipitation values were mapped in Geographical Information Systems (GIS) media by employing Ordinary Cokriging interpolation technique; then, runoff maps of M. Turc method were generated accordingly. Hypsometric curves of runoff values were developed for each runoff case. It was determined that hypsometric curves for $80 \%$ and $90 \%$ probability levels overlapped quite well with the curves of PNI drought category of "Mild Drought" and "Moderate Drought", respectively; and hypsometric curve of $M$. Turc runoff values with 50\% probability level represented the curve relating to the runoff threshold values for PNI drought category of "Normal and Over, i.e. No Risk". Consequently, the use of M. Turc runoff values with 50\% probability level was not found suitable for the capacity design of small earthen dams lying in the Seyhan River Basin prone to drought risk. Hence, it was suggested that runoff calculation for the design of reservoirs of small earthen dams should be done by using precipitation data having $80 \%$ or $90 \%$ probability levels in order to reduce construction costs.

Keywords: Percent of Normal Precipitation Index (PNI), drought, GIS, M. Turc runoff.

\section{GİRiș}

$\mathrm{Su}$; biyolojik hayatın devamlılığı bakımından en önemli gereksinimdir [1]. Dünya nüfusunun 2/3'ünün 2025 yılına kadar su kıtlığı çeken bölgelerde yaşayacağı öngörülmektedir [2-5]. Devlet Su İşleri (DSI) [6] tarafindan, kişi başına su miktarı $10000 \mathrm{~m}^{3}$ yıl ${ }^{-1}$ olan ülkeler su potansiyeli bakımından zengin ülke olarak kabul edilmektedir. Türkiye'de ise kişi başına düşen su miktarı $1430 \mathrm{~m}^{3} \mathrm{y}^{-1}{ }^{-1}$ 'dır [7, 8]. Türkiye nüfusunun 2040'lı yıllarda 100 milyona ulaşacağı dikkate alındığında; kişi başına düşen kullanılabilir yaklaşık su miktarının 1120 $\mathrm{m}^{3} \mathrm{y}_{1} \mathrm{l}^{-1}$ ile "su fakiri" bir ülke olacağı aşikardır.

Kuraklık; akış ve yağışların doğal olarak azalması nedeniyle su yönetimi ve canlılığın devamı açısından gerekli suyun sağlanamadığı zaman periyodudur [9]. Canlıların ihtiyaç duyduğu suyun miktarındaki azalmaya bağlı olarak ortaya çıkan kuraklık çeşitleri sırasıyla meteorolojik, tarımsal, hidrolojik ve sosyo-ekonomik kuraklık olarak adlandırılırlar. İklim değişikliğinin sıcak gün ve sıcak hava dalgalarının süre ve frekansını artırması, kuraklık şiddetinin artmasına neden olabilmektedir [10]. Zira, son on yıldır diğer doğal afetlere nazaran kuraklığın tekrarlanma sayısının arttığı görülmektedir [1]. Kuzey Afrika, Hindistan'ın bir kısmı, Kuzey Çin, Orta Doğu, Orta Asya, Güney Batı Avrupa, Avusturalya, Kanada ve Batı Amerika'da kurak ve yarı kurak bölgelerde yaşayan nüfusun \%40’1 periyodik 
olarak kuraklıkla yüz yüzedir. Amerika Birleşik Devletlerinde yıllık ortalama 6-8 milyar \$ kuraklık nedeniyle ekonomik zarar oluşmaktadır [11,12]. Avrupa'da, kuraklığın ekonomiye verdiği zarar son 30 yılda 116 milyar \$ dolayındadır. Ülkemizde ise; $2007^{`}$ de meydana gelen kuraklığın verdiği zarar 2.5 milyar \$'dır [13]. Alınacak önlemlerle kuraklığın vereceği zararları azaltabilmek mümkündür. Yağışlar sonucu oluşan yüzey(sel) akış sularının depolandığı su hasadı tekniklerinin uygulamaya konulması, kuraklık kaynaklı zararlara karşı önleyici tedbirlerden sadece birisidir [14]. Göletler bir su hasadı tekniği olup; kış ve bahar aylarında boşa giden yüzey akış sularını depolayan, barajlara göre inşaat maliyeti daha az olan, genelde tarımsal ve hayvan içme suyu amaçlı su depolama tesisleridir [15-19]. Kişi başına düşen su miktarındaki azalmalar ve yakın gelecekte beklenen olası kuraklık riski, yarı kurak iklim kuşağında yer alan ülkemizdeki su depolama tesislerinin sayısının artırılması gerektiğini göstermektedir [20,21]. Ayrıca, göletlerin rezervuar kapasitesinin yıl içindeki doluluk oranı dikkate alınarak kuraklık ile ilgili öngörülerde bulunmak mümkündür [22]. Ön etüd raporlarına göre yurdumuzda on bin göletin yapılabileceği belirlenmiştir [23]. Ancak, göletler çoğunlukla akım gözlemleri olmayan kuru dereler üzerine tesis edilmektedir [24]. Bu nedenle, ülkemizde DSİ ve İl Özel İdareler tarafından gölet kapasitesinin saptanmasında en önemli parametre olan yıllık toplam akışın hesaplanmasında en çok M. Turc ampirik yöntemi kullanılmaktadır. Hesaplamalarda havzayı temsil ettiği varsayılan istasyonun $\% 50$, $\% 80$ ve $\% 90$ olasılıkla beklenen alansal yıllık toplam yağış ve yıllık ortalama sıcaklık serileri kullanılarak gölet rezervuar tasarımı yapılmaktadır [18, 25, 26]. Akım gözlemi olmayan dereler üzerinde planlanan göletlerin rezervuar hacminin hangi olasılık düzeyine göre tasarlanacağ 1 ise, genellikle mühendislerin tecrübesine göre belirlenmektedir. Üstelik, bu olasllık değerlerine göre hesaplanan havza su verimlerinde kuraklık da dikkate alınmamaktadır. Oysa, tüm bölgelerde ve mevsimlerde oluşabilen meteorolojik, tarımsal ve hidrolojik kuraklık; 1970'lerin başından beri ülkemizde daha sık ve şiddetli [27-29] oluşabilmektedir. Türkiye'nin dünya üzerinde kuraklığın sürekli tehdit oluşturduğu yarı kurak bir kuşakta yer alması [30, 31], gölet tasarımına yönelik havza su verimi hesaplamalarında kuraklığın dikkate alınması gerekliliğini sorgulanır hale getirmiştir. Çünkü, havza su veriminin fazla hesaplanması gölet haznesinin boyutlarının gereksiz büyümesine neden olabilmektedir.

Seyhan Havzası'nda iklim değişikliğinin; kar depolaması, yüzey ve yer altı su potansiyelinde \%30'a varan azalışlara neden olacağı tahmin edilmektedir [32, 33]. Havzada, beklenen yağışlarda \%30-35 arasında bir azalma ve 2070 yılında hava sıcaklığının $2-3.5^{\circ} \mathrm{C}$ arasında artacağı da öngörüler arasındadır [34]. Ayrıca, Seyhan Havzası'nda iki farklı küresel iklim modeli kullanılarak hesaplanan yıllık su akımının tüm havzada on yıllık periyotta \%20 ile \%30 arasında azalacağı ortaya konulmuştur [35]. Bir çok araştırma sonucunda; Seyhan Havzası'nda daha şiddetli kurak dönemlerin görülme olasıllğının yüksek ve havzanın kuraklığa eğilimli olduğu vurgulanmıştır [36-41]. Dolayısıyla, Seyhan Havzası'nda akım gözlemi olmayan dereler üzerinde tasarlanacak göletlerin, ekonomik maliyet bakımından hangi olasıllı düzeyine göre dizayn edilmesi proje mühendisinin çözmek zorunda olduğu problemlerden bir tanesidir. Bir örnek verilecek olursa; Osmaniye İli Bahçe İlçesi Yaylalık Göleti projesinde; $1.5 \mathrm{~km}^{2}$ lik havzadan $\% 50, \% 80$ ve $\% 90$ olasılıkla beklenen alansal yıllık toplam yüzey akış miktarları $M$. Turc yöntemiyle sayıldığı sıraya göre; $674311 \mathrm{~m}^{3} \mathrm{yll}^{-1}$, $463930 \mathrm{~m}^{3} \mathrm{yll}^{-1}$ ve $375561 \mathrm{~m}^{3} \mathrm{yll}^{-1}$ olarak hesaplanmıştır. Görüldüğü üzere $\% 50$ ve $\% 90$ olasılıkla beklenen yıllık toplam havza su verimleri arasında yaklaşı 2 katına yakın fark vardır. Proje tasarımı için seçilen olasılık değeri gölet gövde yüksekliğini, gövde dolgu 
hacmini, işçilik giderlerini dolayısıyla da maliyeti doğrudan etkilemektedir. DSİ tarafından 2015 yılında tamamlanan 1000 günde 1001 gölet (Göl-Su) projesinde ortalama büyük ölçekli bir sulama göletinin maliyeti 2018 yılı itibarıyla 1090153 \$'dır [42]. Hatay ve Osmaniye İl Özel İdareleri tarafından yapılan orta ölçekli sulama göletlerinin ortalama maliyeti ise yaklaşık 729439 \$'dır. Gölet tasarımında maliyeti azaltabilmek için kurak dönemlerin dikkate alınması, ekonomik açıdan büyük tasarruf sağlayabilecektir. Bu nedenle; kuraklık riskini dikkate alarak $\% 50, \% 80$ ve $\% 90$ olasılıklı havza su verimi miktarlarından optimal gövde yüksekliğini verecek olasılık düzeylerinin ne olması gerektiğinin belirlenmesi büyük önem ve ihtiyaç arz etmektedir.

Bu çalışmada:

1. Meteorolojik kuraklığın izlenebildiğgi, yalnızca yağış verisine ihtiyaç duyan Normalin Yüzdesi Kuraklık Indeksi (NYI) yöntemi kullanılarak Seyhan Havzası'nda kuraklık sınıflaması yapılması; kuraklık riski olmayan "normal ve üzeri", izlemeye başlanması gereken "hafif kurak", uyarı "orta şiddette kurak" ve acil durumu ifade eden "şiddetli kurak" kategorileri için "kuraklık eşik yă̆ış" değerlerinin saptanması; $N Y \dot{I}=\% 65$, $N Y \dot{I}=\% 75$ ve $N Y \dot{I}=\% 85$ "kuraklık eşik yă̆lş" esas alınarak istasyon bazında M. Turc yöntemiyle $Q_{N Y I=\% 65}, Q_{N Y I=\% 75}$ ve $Q_{N Y I=\% 85}$ eşik yüzey akış haritalarının geliştirilmesi,

2. Seyhan Havzası'nda istasyon bazında hesaplanan $\% 50, \% 80$ ve $\% 90$ olasılıkla beklenen toplam yağış değerleri kullanılarak $Q_{\% 50}, Q_{\% 80}$ ve $Q_{\% 90}$ olasılıklı $M$. Turc yüzey akış haritalarının oluşturulması,

3. $Q_{N Y I=\% 65}, Q_{N Y I=\% 75}$ ve $Q_{N Y I=\% 85}$ eşik yüzey akış haritaları ile $Q_{\% 50}, Q_{\% 80}$ ve $Q_{\% 90}$ olasıllklı yüzey akış haritalarına ilişkin “yüzey akış hipsometrik eğrileri” "nin geliştirilmesi ve bu eğrilerin karşılaştırılması; karşılaştırma sonucuna göre, akım gözlemi olmayan kuraklığa eğilimli bölgelerde tasarlanacak göletlerin havza su verimi hesabında kullanılabilecek olasılık düzeyinin belirlenmesi amaçlanmıştır.

\section{MATERYAL VE YÖNTEM}

\section{1. Çalışma Alanı, Kullanılan Veriler ve Verilerin Kaynağı}

$\mathrm{Bu}$ araştırma; Türkiye'nin güneyinde yer alan Seyhan Havzası'nda yapılmıştır. Havza, $21470.3 \mathrm{~km}^{2}$ [43] genişliğinde ve kuzey-güney doğrultusundadır (Şekil 1a).

Araştırmada, Meteoroloji Genel Müdürlüğü'ne ait Seyhan Havzası içinde ve havza sınırına yakın kesimlerde yer alan, Şekil 1a'da gösterilen 63 adet meteoroloji gözlem istasyonunun uzun yıllık (1950-2006) toplam yağış serileri, havzanın sayısal yükseklik verileri ve \%50 olasılıklı sıcaklık değerleri kullanılmıştır (Şekil 1b). Seyhan Havzasına ait Sayısal Yükseklik Modeli (SYM) haritası, 1/250 000 ölçekli topoğrafik haritalar sayısallaştırılarak [44] $250 \mathrm{~m} \times 250 \mathrm{~m}$ çözünürlükte üretilmiş (Şekil 1a) ve $C B S$ ortamında yapılan hesaplamalarda altlık olarak kullanılmıştır. Yüzey akış hesaplamalarında gereksinim duyulan \%50 olasılıklı ortalama sıcaklık $\left(\mathrm{T}_{\% 50}\right)$ verileri, $250 \mathrm{~m} \times 250 \mathrm{~m}$ çözünürlükte Keskiner ve ark. [45] tarafından üretilen ve Şekil 1b'de verilen raster tabanlı haritadan elde edilmiştir. 


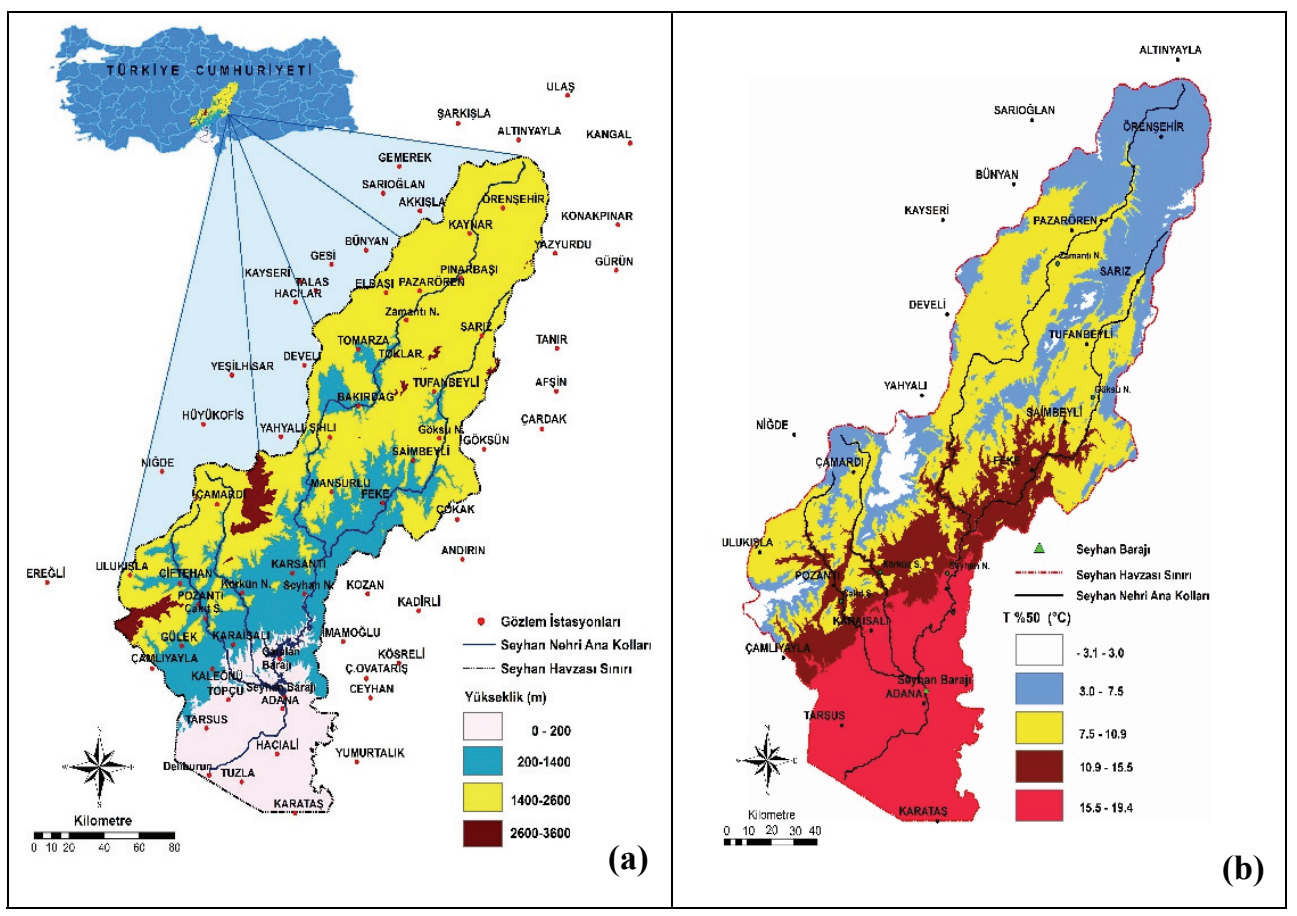

Şekil 1 - a) Seyhan Havzası'nın konumu, b) \%50 olasıllklı ortalama sıcaklı haritası

\subsection{Yöntem}

\subsubsection{Regresyon Analizi}

Araştırmada kullanılan yağış istasyonlarının yıllık toplam yağış $(Y)$ serisinde yer alan eksik veriler, Eşitlik 1'deki Doğrusal, Kuadratik ve Kübik regresyon modellerinden biri kullanılarak Ryan ve Cryer [46] 'e göre tamamlanmıştır. Verisi tamamlanacak istasyonla en yüksek korelasyonu olan komşu istasyon; konum, istasyon yüksekliği, gözlem sürelerinin uygunluğu ve ara mesafeler dikkate alınarak belirlenmiştir. En yüksek korelasyona sahip iki istasyon kullanılarak, en uygun regresyon modeline, determinasyon katsayısı $\left(R^{2}\right)$ esas alınarak karar verilmiştir.

$$
\begin{aligned}
& Y=b_{0}+b_{1} X+e \\
& Y=b_{0}+b_{1} X+b_{2} X^{2}+e \\
& Y=b_{0}+b_{1} X+b_{2} X^{2}+b_{3} X^{3}+e
\end{aligned}
$$

Burada: $Y, X, b_{i}$ ve $e$ sırasıyla bağımlı ve bağımsız değişkeni; regresyon katsayılarını ve hata terimini göstermektedir. 


\subsubsection{Frekans Analizi}

Araştırma alanındaki her istasyonun uzun yıllık toplam yăğı̧ serisinin frekans analizleri BestFit [47] ortamında yapılmıştır. Olasılık dağılımlarının uygunluk testleri, \%5 güven düzeyinde Kolmogorov-Smirnov testi ile gerçekleştirilmiştir [48]. Belirlenen dağılımlara ilişkin "frekans faktör eşitliği" [49] kullanılmak suretiyle M.Turc yönteminde gereksinim duyulan $\% 50, \% 80$ ve $\% 90$ olasılıklı yağış değerleri her istasyon için ayrı ayrı kestirilmiştir (Eşitlik 2).

$$
X_{p \%}=\bar{X}+K_{p \%} S
$$

Burada: $S$, standart sapmayı; $\bar{x}$, frekans analizine tabi tutulan veri setinin ortalamasını; $X_{p \%}$, incelenen değişkenin belirlenen olasılık düzeyinde $\left(P_{\%}\right)$ beklenen değerini ve $K_{p \%}$, frekans faktörünü göstermektedir.

\subsubsection{Normalin Yüzdesi İndeksi (NYi)}

Şen [50] tarafından belirtildiği gibi, NYİ kuraklık indeksi; belirlenen zaman dilimi içinde gerçekleşen yağış miktarının ortalamasına bölünmesiyle hesaplanır (Eşitlik 3). NYİ; aylık, mevsimlik ya da yıllık periyotlarda gerçekleştirilen meteorolojik ve tarımsal kuraklıkla ilgili çalışmalarda kullanılmaktadır [51]. Normal dağılım göstermeyen çarpık dağılımlarla ifade edilen yağış serilerinin ortalamalarının proje kriteri olarak kullanılması, sakıncalı olup [50, $52,53]$, yöntemin uygulanmasını kısıtlamaktadır. Bu nedenle; yıllık toplam yağış serilerinin frekans analizi sonucu bulunan $\% 50$ olasıllkla beklenen yağış değerleri, NYİ hesaplamalarında ortalama yağış yerine kullanılmaktadır [52]. $N Y \dot{I}$ yöntemine göre kuraklık sinıflaması, Çizelge 1 'deki eşik değerlere $(N Y \dot{I}=\% 85, N Y \dot{I}=\% 75$ ve $N Y \dot{I}=\% 65)$ göre yapılmıştır. Kuraklık sınıflarına karşılık gelen eşik yağış değerleri ise, istasyonların \%50 olasılıklı yağış değerlerinin Eşitlik 3'te kullanılmasıyla kestirilmiştir. Çizelge 1'de gösterilen $N Y I$ değerleri; Ocak-Aralık periyodunu temsil eden 12 aylık zaman dilimi içindir.

$$
N Y I_{i y}=\left(\frac{P_{i y}}{P_{i o r t}}\right) 100
$$

Bu eşitlikte: $i$, gözlem istasyonunu; $y$, Çizelge 1'de verilen kuraklık kategorilerini ( $y=1$ "Risk Yok", $y=2$ "Hafif Kurak", $y=3$ "Uyarl”, $y=4$ "Acil Durum"); $N Y \dot{I}_{i y}, i$ istasyonu için $y$ kuraklık kategorisini; $P_{i y}, i$ istasyonunda $y$ kuraklık kategorisine karşılık yıllık toplam yağış miktarını (mm); $P_{\text {iort }}, i$ istasyonunda $\% 50$ olasılıkla beklenen yıllık toplam yağışı $(\mathrm{mm})$ temsil etmekte olup, aritmetik ortalamanın yerine ikame edilmiştir.

Çizelge 1 - NYİ yöntemi kuraklık sinıflandırması [54]

\begin{tabular}{ccccc}
\hline Periyot & $\begin{array}{c}\text { Normal ve Üzeri } \\
\text { (Risk Yok) }\end{array}$ & $\begin{array}{c}\text { Hafif Kurak } \\
\text { (İzlemeye Başla) }\end{array}$ & $\begin{array}{c}\text { Orta Şiddette Kurak } \\
\text { (Uyari) }\end{array}$ & $\begin{array}{c}\text { Şiddetli Kurak } \\
\text { (Acil Durum) }\end{array}$ \\
\hline 12 & $\mathrm{NYI}>\% 85$ & $\% 75<\mathrm{NY} \dot{\mathrm{I}} \leq \% 85$ & $\% 65 \leq \mathrm{NY} \dot{\mathrm{I}} \leq \% 75$ & $\mathrm{NY} \dot{\mathrm{I}}<\% 65$ \\
\hline
\end{tabular}




\subsubsection{Jeoistatistik Analiz}

Ordinary Cokriging enterpolasyon yöntemi yardımıyla gözlemi olmayan bir noktanın olası değerinin kestiriminde, gözlem değerlerinin deneysel Covariogram yapısına uyan teorik Covariaogram modeli ve bu modelin parametreleri ile Cokriging tahmin parametreleri kullanmaktadır. Hidroloji alanındaki çalışmalarda, gözlem alanı içerisindeki uzaysal bağımlılık yapısı genellikle Küresel, Doğrusal ve Gauss tip yarıvariogram modelleri ile temsil edilebilmektedir [55-58]. Yöntem ile tahmin yapılırken, gözlenen değerlerin yanı sıra yardımcı bir değişkenden daha faydalanılmaktadır [44]. Bu araştırmada, olasılıklı yağış değerlerinin haritalanmasında, Seyhan Havzası SYM görüntüsü hesaplamalara yardımcı değişken olarak dahil edilmiştir. Bu amaçla, Covariogram modeli ve parametreleri [59, 60] belirlenmiş; Cokriging tahminleri yapılmıştır. Covariogram ve Cokriging tahmin tekniklerine ilişkin matematiksel eşitlikler, Goovaerts [61]'de ayrıntılı olarak bulunabilir.

\subsubsection{Turc Yöntemi}

M. Turc, dünyanın bütün iklimlerinde ve 254 havza üzerinde yaptığ 1 gözlemlere dayanarak bulduğu akım açığı ve yüzey akışı (havza su verimini); Eşitlik 4'te verilen denklem takımı ile ifade etmiştir [24, 62]. CBS ortamında, M. Turc yöntemi kullanılarak amaçlanan yüzey akış haritalarını elde etmek için ArcGIS yazılımının Map Algebra modülü kullanılmıştır. Bu modül yardımıyla; $N Y \dot{I}=\% 65, N Y \dot{I}=\% 75$ ve $N Y \dot{I}=\% 85$ kuraklık sınıflaması eşik yağış değerleri baz alınarak istasyon bazında $M$. Turc yöntemiyle $Q_{N Y I=\% 65}, Q_{N Y I=\% 75}$ ve $Q_{N Y I=\% 85}$ eşik yüzey akış haritaları elde edilmiştir. Ayrıca, Seyhan Havzası'nın istasyon bazında hesaplanan $\% 50, \% 80$ ve $\% 90$ olasılıkla beklenen toplam yağış değerleri kullanılmış; $Q_{\% 50}$, $Q_{\% 80}$ ve $Q_{\% 90}$ olasılıklı $M$. Turc yüzey akış haritaları oluşturulmuştur. Yüzey akış haritalarının oluşturulabilmesi için havzadaki istasyonların ortalama sıcaklık değerleri yerine Şekil 1b'de verilen Seyhan Havzası'nın \%50 olasılıkla beklenen ortalama sicaklık $\left({ }^{\circ} \mathrm{C}\right)$ haritasından faydalanılmıştır [45].

$$
\left.\begin{array}{l}
D=\frac{P}{\sqrt{0.9+(P / L)^{2}}} \\
L=A+25 T+0.05 T^{3}, Q=P-D
\end{array}\right\}
$$

Burada;

$L$ : Sıcaklık (T) ve havzaya özgü $A$ katsayısının bir fonksiyonu olup, Seyhan Havzası için $A$ katsayısı 6 alınmaktadır [24],

D: Akım Açığı-Havzada Tutulan Su-Havzadaki Kayıp; NYİ yöntemi \%65, \%75, \%85 göstergesi olan eşik akım açığı ve \%50, \%80, \%90 olasılıkla beklenen akım açığ1 değerleri (mm),

Q: Yüzey Akış-Havza Su Verimi; NYI yöntemi \%65, \%75, \%85 göstergesi olan eşik yüzey akış ve $\% 50, \% 80, \% 90$ olasıllkla beklenen yüzey akış değerleri (mm),

$P$ : Havzada NYİ yöntemi $\% 65, \% 75, \% 85$ göstergesi olan eşik yağış ve $\% 50, \% 80, \% 90$ olasılıkla beklenen yıllık toplam yağış değerleri $(\mathrm{mm})$,

$T$ : Havzada \%50 olasılıkla beklenen yıllık ortalama sıcaklıktır $\left({ }^{\circ} \mathrm{C}\right)$. 


\subsubsection{Yüzey Akış Hipsometrik Ĕgrilerinin Grafiksel Analizi}

Yüzey akış hipsometrik eğrileri, yükseklik-alan dağılımında olduğu gibi [49], yüzey akış alan dağılımını tasvir etmektedir. Bu eğriler; yüzey akış ve yer altı suyu akışı ile ilgili çalışmalarda uyarlanabilmektedir [63]. Bu araştırmada, M. Turc yöntemiyle oluşturulan $Q_{N Y I=\% 65}$, $Q_{N Y I=\% 75}, Q_{N Y I=\% 85}$ eşik yüzey akış haritaları ile $Q_{\% 50}, Q_{\% 80}, Q_{\% 90}$ olasılıkla beklenen yüzey akış haritalarının $250 \mathrm{~m}$ x $250 \mathrm{~m}$ çözünürlükteki raster formatındaki haritaları yüzey akış hipsometrik eğrilerinin geliştirilmesinde kullanılmıştır. Hipsometrik eğrilerin geliştirilmesinde, havzadaki piksellerdeki yüzey akış değerleri ve bu piksellerin alanlarından yararlanılmıştır.

\section{ARAŞTIRMA BULGULARI}

\subsection{Regresyon Analizi Sonuçları}

Havza içerisinde ve çevresinde yer alan 63 adet istasyondan kayıt uzunluğu 15 yıldan az olan istasyonlar tespit edilmiştir. Bu istasyonların eksik yıllık yağış verileri regresyon yöntemi ile komşu istasyon verileri kullanılarak serileri 15 yıla tamamlanmıştır. Örenşehir istasyonu, önemli bir konumda bulunduğundan, bu istasyonun 12 yıllık verisi tamamlanmıştır. Diğer istasyonların tamamlanan yıl sayısı 7 yıl ve daha küçük olup, 18 istasyon dikkate alındığında ortalama 4.8 yıllık veri tamamlanmıştır (Çizelge 2).

Çizelge 2 - Yıllık toplam yă̆ış gözlem serilerindeki eksik verilerin tamamlanması işleminde regresyon model denkleminde kullantlan istasyonlar

\begin{tabular}{ccccccc}
\hline No & $\begin{array}{c}\text { Serisi Uzatılan } \\
\text { Bağımlı } \\
\text { Değişken } \\
\text { Olarak } \\
\text { Kullanılan } \\
\text { İstasyonlar } \\
\text { (Y) }\end{array}$ & $\begin{array}{c}\text { Bağımsız } \\
\text { Değişken } \\
\text { Olarak } \\
\text { Kullanılan } \\
\text { İstasyonlar } \\
\mathbf{( X )}\end{array}$ & $\begin{array}{c}\text { Mevcut } \\
\text { Gözlem } \\
\text { Süresi } \\
(\mathbf{Y} \mathbf{l})\end{array}$ & $\begin{array}{c}\text { Tamamlanan } \\
\text { Süre } \\
(\text { Yıl) }\end{array}$ & $\begin{array}{c}\text { Model } \\
\text { Determinasyon } \\
\text { Katsayısı } \\
\left(\mathbf{\%} \mathbf{R}^{\mathbf{2}}\right)\end{array}$ & $\begin{array}{c}\text { Kullanılan } \\
\text { Model } \\
\text { (Eşitlik 1) }\end{array}$ \\
\hline 1 & Altınyayla & Şarkışla & 8 & 7 & 72.5 & Kübik \\
\hline 2 & Andırın & Feke & 12 & 3 & 70.3 & Doğrusal \\
\hline 3 & Bünyan & Kayseri & 13 & 2 & 61.6 & Doğrusal \\
\hline 4 & Ç.Ovatariş & Ceyhan & 11 & 4 & 60.6 & Kübik \\
\hline 5 & Çamliyayla & Karaisalı & 10 & 5 & 93.8 & Kuadratik \\
\hline 6 & Çardak & Göksün & 8 & 7 & 82.4 & Kübik \\
\hline 7 & Elbaş1 & Kayseri & 11 & 4 & 99.4 & Kuadratik \\
\hline 8 & Gesi & Bünyan & 11 & 4 & 82.1 & Doğrusal \\
\hline 9 & Hacıali & Adana & 14 & 1 & 84.5 & Kuadratik \\
\hline 10 & Hacılar & Kayseri & 9 & 6 & 76.6 & Doğrusal \\
\hline 11 & Kadirli & Kozan & 9 & 6 & 51.2 & Doğrusal \\
\hline & & & & & &
\end{tabular}


Çizelge 2 - Yıllık toplam yağış gözlem serilerindeki eksik verilerin tamamlanması işleminde regresyon model denkleminde kullanılan istasyonlar (devam)

\begin{tabular}{|c|c|c|c|c|c|c|}
\hline No & $\begin{array}{c}\text { Serisi Uzatılan } \\
\text { Bağımlı } \\
\text { Değişken } \\
\text { Olarak } \\
\text { Kullanılan } \\
\text { İstasyonlar } \\
\text { (Y) } \\
\end{array}$ & $\begin{array}{l}\text { Bağımsız } \\
\text { Değişken } \\
\text { Olarak } \\
\text { Kullanılan } \\
\text { İstasyonlar } \\
\text { (X) }\end{array}$ & $\begin{array}{c}\text { Mevcut } \\
\text { Gözlem } \\
\text { Süresi } \\
\text { (Yıl) }\end{array}$ & $\begin{array}{c}\text { Tamamlanan } \\
\text { Süre } \\
\text { (Yıl) }\end{array}$ & $\begin{array}{c}\text { Model } \\
\text { Determinasyon } \\
\text { Katsayısı } \\
\left(\% \mathbf{R}^{2}\right)\end{array}$ & $\begin{array}{c}\text { Kullanılan } \\
\text { Model } \\
\text { (Eşitlik 1) }\end{array}$ \\
\hline 12 & Pazarören & Kayseri & 9 & 6 & 87.2 & Doğrusal \\
\hline 13 & Örenşehir & Bünyan & 3 & 12 & 99.5 & Doğrusal \\
\hline 14 & Saimbeyli & Tufanbeyli & 10 & 5 & 91.2 & Kuadratik \\
\hline 15 & Tarsus & Adana & 13 & 2 & 74.2 & Doğrusal \\
\hline 16 & Tuzla & Adana & 11 & 4 & 84.2 & Kuadratik \\
\hline 17 & Yahyalı & Niğde & 13 & 2 & 91.1 & Kübik \\
\hline 18 & Yeşilhisar & Develi & 8 & 7 & 92.6 & Kuadratik \\
\hline
\end{tabular}

Serilerin tamamlanmasında ilişkilendirilecek istasyonların öncelikle Pearson korelasyon katsayısına bakılmıştır. Pearson korelasyon katsayısı dikkate alınarak, $r \geq 0.5$ koşulunu sağlayan istasyonların doğrusal, kuadratik ve kübik matematiksel ilişski modelleri oluşturulmuştur. Oluşturulan modellerden standart sapması en küçük, determinasyon katsayısı $\left(R^{2}\right)$ en büyük olan model, eksik serilerin uzatılmasında kullanılmıştır. Standart sapmaları bir birine yakın olan farklı modellerin olması durumunda, daha az parametre içeren modeller tercih edilmiştir. Bunun sebebi, doğrusal olmayan ilişkilerde parametre sayısının artması nedeniyle verilerdeki küçük değişimler, diğer istasyonun hesaplanan veri değerlerinde büyük farklılıklara neden olabilmektedir. Diğer bir ifadeyle; iyi bir ilişki modeli oluşturmak için benzer olasılık dağılımlarına sahip olan istasyonlar ve daha az paremetreli modeller kullanılarak daha gerçekçi tahminler yapılabilmektedir [64].

\subsection{Frekans Analizi Sonuçları}

Seyhan Havza içerisinde ve çevresinde yer alan 63 adet istasyonun frekans analizi yapılmıştır. Araşı̧ımada kullanılan meteoroloji gözlem istasyonlarının etki alanları Thiessen poligonları ile belirlenmiş ve yıllık toplam yağış serilerinin uyduğu olasılık dağılımları Şekil 2'de verilmiştir.

Frekans analizi sonucunda yıllık toplam yağış serileri 10 farklı olasılık dağılımı ile temsil edilmiştir. İstasyonların; 24'ü Lojistik, 9'u Log-Lojistik, 8'i Normal, 5'i Genel Beta, 5'i Weibull, 4'ü Ekstrem Değer, 3'ü Rayleigh, 2'si Tersgauss, 2'si Lognormal_2 ve 1'i Pearson_5 dağılımları ile ifade edilmiştir. Bu sonuçlara göre; Seyhan Havzası içinde ve dışında bulunan 63 adet meteoroloji gözlem istasyonu arasında \%38 oranıyla Lojistik dağılımın hakim olduğu görülmüştür. Seyhan Havzası'nın güneybatı-batı ve kuzeybatısında yer alan Tarsus, Çamlıyayla, Ereğli, Niğde, Hacılar, Bünyan vd. istasyonlar Lojistik dağılımla; düz ve düze yakın olan topoğrafyada yer alan istasyonlar (Tuzla, Hacıali, Topçu, 
Kaleönü ve Karaisalı) ise ağırlıklı olarak Log-Lojistik dağılımla temsil edilmiştir. Buna karşın, yağış ve yüzey akışların en çok gözlendiği Gülek, Pozantı, Karsantı, Mansurlu, Feke, Saimbeyli, Şıhlı, Tufanbeyli, Sarız, Göksün, Çokak vd. istasyonların bulunduğu "Orta Bölge” 7 farklı olasılık dağılımı ile ifade edilmiştir. Bu durum; derin vadilerin bulunduğu "Orta Bölge"deki topoğrafyanın yağış dağılımlarının çeşitlenmesine neden olduğuna dair hipotezi güçlendirmiştir. Frekans analizi sonucunda belirlenen olasılık dağılım modellerinden elde edilen $\% 50, \% 80$ ve $\% 90$ olasılıkla beklenen yıllık toplam yağış değerleri Çizelge 3'te verilmiştir.

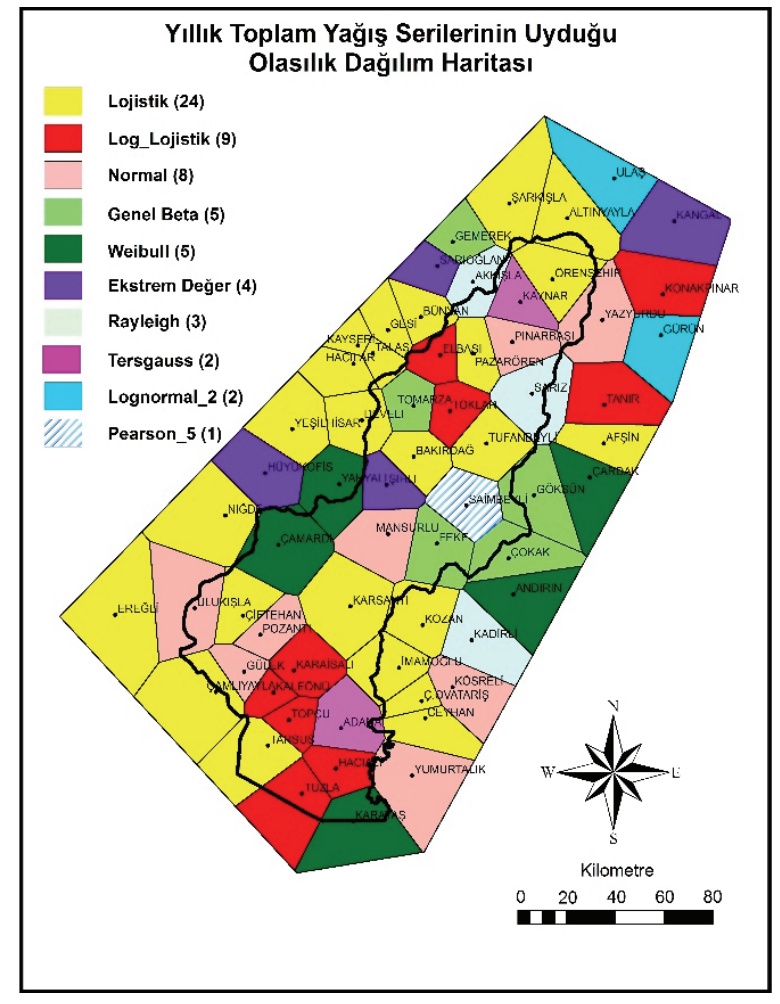

Şekil 2 - Yıllık toplam yă̆ış serilerinin uyduğu olasılık dă̆ılım modelleri

Çizelge 3 - Ístasyonlarda \%50, \%80 ve \%90 olasılıkla beklenen yă̆ış değerleri

\begin{tabular}{|c|c|c|c|c|c|c|c|c|c|}
\hline \multirow[b]{2}{*}{ No } & \multirow[b]{2}{*}{ İstasyon } & \multicolumn{3}{|c|}{ Yağıș $(P, \mathbf{m m})$} & \multirow[b]{2}{*}{ No } & \multirow[b]{2}{*}{ İstasyon } & \multicolumn{3}{|c|}{ Yağıș $(P, \mathbf{m m})$} \\
\hline & & $\% 50$ & $\% 80$ & $\% 90$ & & & $\% 50$ & $\% 80$ & $\% 90$ \\
\hline 1 & Kangal & 395 & 333 & 306 & 33 & Şılhlı & 395 & 345 & 324 \\
\hline 2 & Konakpınar & 390 & 294 & 257 & 34 & Yahyalı & 459 & 377 & 331 \\
\hline 3 & Yazyurdu & 414 & 332 & 289 & 35 & Hüyükofis & 331 & 249 & 215 \\
\hline 4 & Ulaş & 352 & 294 & 273 & 36 & Niğde & 332 & 289 & 264 \\
\hline 5 & Altınyayla & 319 & 285 & 266 & 37 & Çamard 1 & 370 & 290 & 249 \\
\hline
\end{tabular}


Çizelge 3 - İstasyonlarda \%50, \%80 ve \%90 olasılıkla beklenen yağış değerleri (devam)

\begin{tabular}{|c|c|c|c|c|c|c|c|c|c|}
\hline \multirow[b]{2}{*}{ No } & \multirow[b]{2}{*}{ İstasyon } & \multicolumn{3}{|c|}{ Yağıș $(P, \mathbf{m m})$} & \multirow[b]{2}{*}{ No } & \multirow[b]{2}{*}{ İstasyon } & \multicolumn{3}{|c|}{ Yağıș $(P, \mathbf{m m})$} \\
\hline & & $\% 50$ & $\% 80$ & $\% 90$ & & & $\% 50$ & $\% 80$ & $\% 90$ \\
\hline 6 & Şarkışla & 322 & 269 & 239 & 38 & Mansurlu & 971 & 775 & 673 \\
\hline 7 & Gemerek & 391 & 342 & 321 & 39 & Feke & 934 & 676 & 642 \\
\hline 8 & Sarığlan & 378 & 329 & 307 & 40 & Saimbeyli & 833 & 707 & 659 \\
\hline 9 & Akkışla & 420 & 370 & 349 & 41 & Çokak & 1472 & 1041 & 964 \\
\hline 10 & Kaynar & 333 & 296 & 277 & 42 & Andirın & 1399 & 1151 & 1043 \\
\hline 11 & Örenşehir & 311 & 240 & 199 & 43 & Karsant1 & 1035 & 805 & 670 \\
\hline 12 & Gürün & 305 & 255 & 230 & 44 & Çiftehan & 493 & 345 & 258 \\
\hline 13 & Pınarbaş1 & 410 & 339 & 302 & 45 & Ulukışla & 321 & 268 & 240 \\
\hline 14 & Pazarören & 391 & 347 & 322 & 46 & Ereğli & 293 & 249 & 222 \\
\hline 15 & Elbaş1 & 381 & 363 & 354 & 47 & Pozantı & 701 & 517 & 420 \\
\hline 16 & Bünyan & 463 & 400 & 364 & 48 & Gülek & 868 & 667 & 563 \\
\hline 17 & Gesi & 407 & 352 & 320 & 49 & Çamlıyayla & 1020 & 905 & 838 \\
\hline 18 & Talas & 369 & 309 & 273 & 50 & Karaisalı & 898 & 725 & 632 \\
\hline 19 & Kayseri & 394 & 332 & 296 & 51 & İmamoğlu & 675 & 548 & 474 \\
\hline 20 & Hacilar & 513 & 449 & 412 & 52 & Kösreli & 661 & 539 & 475 \\
\hline 21 & Yeşilhisar & 274 & 241 & 222 & 53 & Ç.Ovatariş & 806 & 685 & 615 \\
\hline 22 & Develi & 368 & 318 & 289 & 54 & Ceyhan & 709 & 586 & 514 \\
\hline 23 & Tomarza & 394 & 340 & 316 & 55 & Yumurtalık & 825 & 649 & 557 \\
\hline 24 & Toklar & 381 & 331 & 310 & 56 & Haciali & 612 & 530 & 499 \\
\hline 25 & Adana & 623 & 509 & 468 & 57 & Karataş & 765 & 584 & 501 \\
\hline 26 & Sar1z & 507 & 435 & 405 & 58 & Tuzla & 634 & 501 & 447 \\
\hline 27 & Tanır & 303 & 245 & 221 & 59 & Tarsus & 595 & 484 & 419 \\
\hline 28 & Afşin & 436 & 371 & 333 & 60 & Kozan & 838 & 706 & 629 \\
\hline 29 & Çardak & 562 & 493 & 456 & 61 & Kadirli & 709 & 562 & 501 \\
\hline 30 & Göksün & 614 & 489 & 440 & 62 & Kaleönü & 841 & 750 & 708 \\
\hline 31 & Tufanbeyli & 553 & 467 & 417 & 63 & Topçu & 646 & 527 & 467 \\
\hline 32 & Bakırdağ & 345 & 299 & 272 & & & & & \\
\hline
\end{tabular}

\subsection{Normalin Yüzdesi İndeksi (NYI) Kuraklık Analizi Sonuçları}

Frekans analizi sonucu bulunan yıllık toplam yağış serilerinin $\% 50$ olasılıkla beklenen toplam yağış değerleri, Eşitlik 3 'te ortalama yağış değerine ikame olarak kullanılmış ve NYI değerleri elde edilmiştir. Çizelge 1 ve Eşitlik 3 birlikte değerlendirilerek, her bir istasyonun $N Y \dot{I}=\% 85, N Y \dot{I}=\% 75$ ve $N Y \dot{I}=\% 65$ değerlerine karş1lı gelen "eşik yağış de ğerleri" istasyon bazında hesaplanmıştır (Çizelge 4). 
Kuraklık Riski Altındaki Havzalarda Gölet Haznelerinin Tasarımı: Seyhan Havzası'nda...

Çizelge 4 - İstasyonların $P=\% 50$ olasılıklı yıllık toplam yağış değerlerinden hesaplanan NYI kuraklık kategorilerinin (\%65, \%75, \%85) eşik yağış değerleri (mm)

\begin{tabular}{|c|c|c|c|c|c|c|c|c|c|c|c|}
\hline \multirow[b]{2}{*}{ No } & \multirow[b]{2}{*}{ İstasyon } & \multirow{2}{*}{$\begin{array}{c}P \\
\% 50\end{array}$} & \multicolumn{3}{|c|}{$\begin{array}{c}\text { NYİ Kuraklık } \\
\text { Kategorileri }\end{array}$} & \multirow[b]{2}{*}{ No } & \multirow[b]{2}{*}{ İstasyon } & \multirow{2}{*}{$\begin{array}{c}P \\
\% 50 \\
\end{array}$} & \multicolumn{3}{|c|}{$\begin{array}{c}\text { NYİ Kuraklık } \\
\text { Kategorileri }\end{array}$} \\
\hline & & & $\% 65$ & $\% 75$ & $\% 85$ & & & & $\% 65$ & $\% 75$ & $\% 85$ \\
\hline 1 & Kangal & 395 & 257 & 296 & 336 & 33 & Şıhlı & 395 & 257 & 296 & 335 \\
\hline 2 & Konakpınar & 390 & 254 & 293 & 332 & 34 & Yahyalı & 459 & 299 & 345 & 391 \\
\hline 3 & Yazyurdu & 414 & 269 & 310 & 352 & 35 & Hüyükofis & 331 & 215 & 248 & 281 \\
\hline 4 & Ulaş & 352 & 229 & 264 & 299 & 36 & Niğde & 332 & 216 & 249 & 283 \\
\hline 5 & Altınyayla & 319 & 207 & 239 & 271 & 37 & Çamard 1 & 370 & 240 & 277 & 314 \\
\hline 6 & Şarkışla & 322 & 209 & 241 & 273 & 38 & Mansurlu & 971 & 631 & 728 & 825 \\
\hline 7 & Gemerek & 391 & 254 & 293 & 332 & 39 & Feke & 934 & 607 & 701 & 794 \\
\hline 8 & Sarıoğlan & 378 & 246 & 284 & 322 & 40 & Saimbeyli & 833 & 541 & 624 & 708 \\
\hline 9 & Akkışla & 420 & 273 & 315 & 357 & 41 & Çokak & 1472 & 957 & 1104 & 1251 \\
\hline 10 & Kaynar & 333 & 217 & 250 & 283 & 42 & Andırın & 1399 & 909 & 1049 & 1189 \\
\hline 11 & Örenşehir & 311 & 202 & 233 & 264 & 43 & Karsantı & 1035 & 673 & 776 & 879 \\
\hline 12 & Gürün & 305 & 198 & 229 & 259 & 44 & Çiftehan & 493 & 321 & 370 & 419 \\
\hline 13 & Pınarbaş1 & 410 & 267 & 308 & 349 & 45 & Ulukışla & 321 & 209 & 241 & 273 \\
\hline 14 & Pazarören & 391 & 254 & 293 & 332 & 46 & Ereğli & 293 & 191 & 220 & 249 \\
\hline 15 & Elbaş1 & 381 & 248 & 286 & 324 & 47 & Pozant1 & 701 & 456 & 526 & 596 \\
\hline 16 & Bünyan & 463 & 301 & 347 & 393 & 48 & Gülek & 868 & 564 & 651 & 738 \\
\hline 17 & Gesi & 407 & 264 & 305 & 346 & 49 & Çamlıyayla & 1020 & 663 & 765 & 867 \\
\hline 18 & Talas & 369 & 240 & 276 & 313 & 50 & Karaisalı & 898 & 583 & 673 & 763 \\
\hline 19 & Kayseri & 394 & 256 & 295 & 335 & 51 & İmamoğlu & 675 & 439 & 506 & 574 \\
\hline 20 & Hacılar & 513 & 333 & 385 & 436 & 52 & Kösreli & 661 & 430 & 496 & 562 \\
\hline 21 & Yeşilhisar & 274 & 178 & 205 & 233 & 53 & Ç.Ovatariş & 806 & 524 & 604 & 685 \\
\hline 22 & Develi & 368 & 239 & 276 & 313 & 54 & Ceyhan & 709 & 461 & 532 & 603 \\
\hline 23 & Tomarza & 394 & 256 & 296 & 335 & 55 & Yumurtalık & 825 & 537 & 619 & 702 \\
\hline 24 & Toklar & 381 & 248 & 286 & 324 & 56 & Haciali & 612 & 398 & 459 & 520 \\
\hline 25 & Adana & 623 & 405 & 467 & 530 & 57 & Karataş & 765 & 497 & 574 & 650 \\
\hline 26 & Sarız & 507 & 329 & 380 & 431 & 58 & Tuzla & 634 & 412 & 476 & 539 \\
\hline 27 & Tanır & 303 & 197 & 228 & 258 & 59 & Tarsus & 595 & 387 & 446 & 506 \\
\hline 28 & Afşsin & 436 & 284 & 327 & 371 & 60 & Kozan & 838 & 545 & 628 & 712 \\
\hline 29 & Çardak & 562 & 365 & 422 & 478 & 61 & Kadirli & 709 & 461 & 532 & 603 \\
\hline 30 & Göksün & 614 & 399 & 461 & 522 & 62 & Kaleönü & 841 & 547 & 631 & 715 \\
\hline 31 & Tufanbeyli & 553 & 360 & 415 & 470 & 63 & Topçu & 646 & 420 & 484 & 549 \\
\hline 32 & Bakırdağ & 345 & 224 & 259 & 293 & & & & & & \\
\hline
\end{tabular}




\subsection{Jeoistatistik Analiz Sonuçları}

Yıllık toplam yağış serilerinin \%50, \%80, \%90 olasılıkla beklenen yağış değerleri (Çizelge 3) ve NYI yöntemi $\% 65, \% 75, \% 85$ göstergesi olan eşik yağış değerleri (Çizelge 4) jeoistatistiksel yöntemle analiz edilmiştir. Bu bağlamda, havzanın raster tabanlı sayısal yükseklik modeli yardımcı değişken olarak kullanılmış ve deneysel covariogramlar elde edilmiştir. Dikkate alınan yağış veri setleri, küresel tip teorik covariogram modeli ile temsil edilmiştir. Seyhan Havzası'nda \%50, \%80, \%90 olasılıkla beklenen yılık toplam yağış değerleri ve $N Y \dot{I}$ yöntemine göre $\% 65, \% 75, \% 85$ eşik yağış değerleri Ordinary Cokriging yöntemi ile haritalanmıştır (Şekil 3).

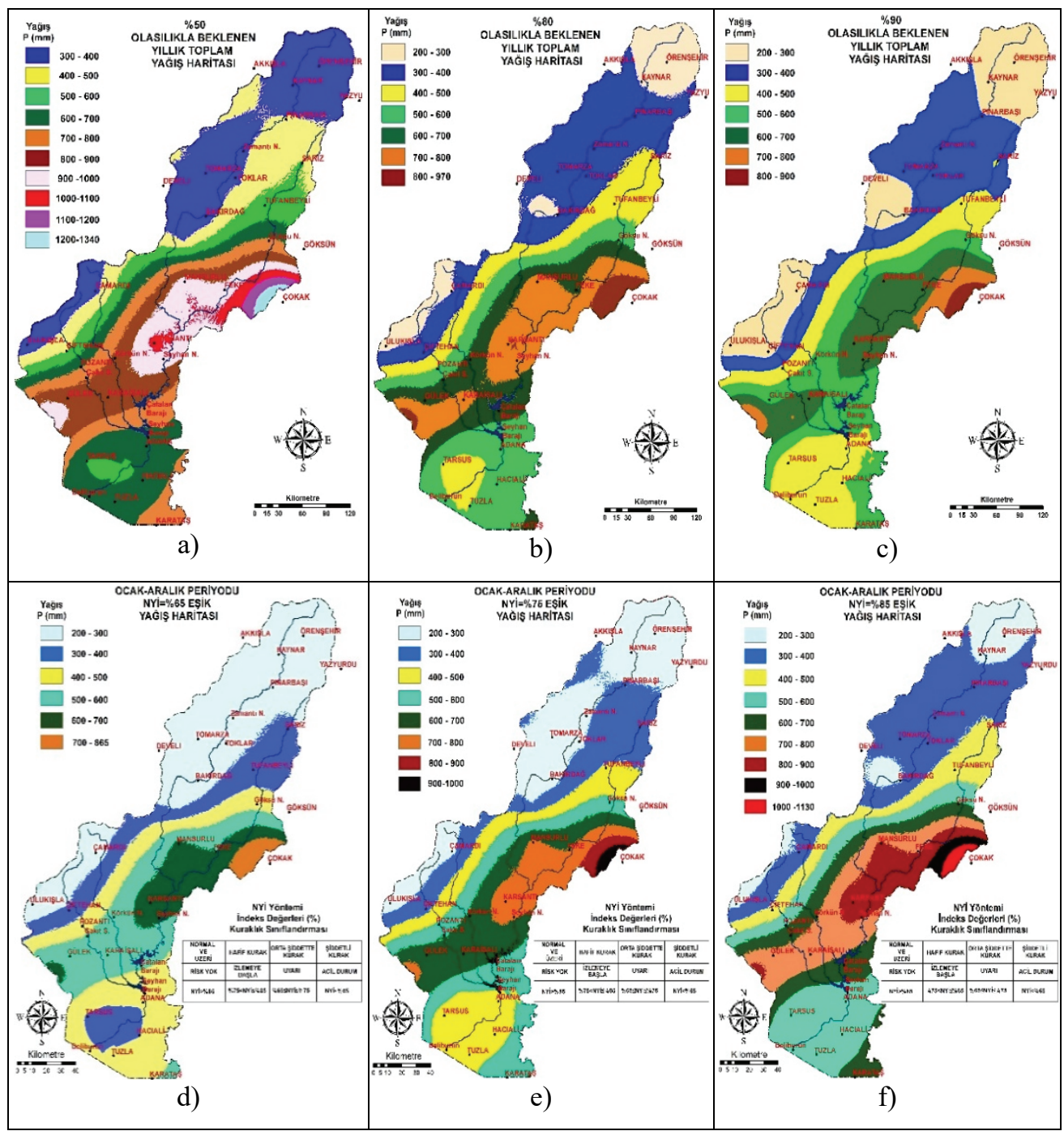

Şekil 3 - Seyhan Havzası'nda farklı olasılıklı (\%50, \%80, \%90) yıllık toplam yağış ve NYI yöntemi farklı kuraklık sınıfları eşik (\%65, \%75, \%85) yağış haritaları 
Seyhan Havzası'nın $S Y M$ haritası incelendiğinde topoğrafya ile yağış dağılımları paralellik göstermektedir. Şekil 3'te verilen yağış haritaları ile Seyhan Havzası'nda yağışlar değerlendirilirken, havzanın orta, kuzey ve güney olarak 3 bölgeye ayrılması daha sağlıklı yorumların yapılmasına olanak sağlamaktadır. Orta bölge olarak adlandırılan Karaisalı, Gülek, Pozantı, Mansurlu ve Çokak'ı da içine alan bölgenin Seyhan Havzası'nı kuzey ve güney olarak iki bölgeye ayırdığı görülmektedir. Bu bölge; Seyhan Havzası'nda yağış dağılımlarının boyun bölgesidir. $\mathrm{Bu}$ bölgede, yağış miktarları kuzeybatı-güneydoğu (Pozantı-Karaisalı) yönünde azalarak, kuzeydoğu-güneybatı (Karsant1-Gülek) yönünde ise artarak geçiş yapmıştır. Diğer bir ifadeyle, orta bölge en yüksek yağış alan bölge olup, SYM haritasında yaklaşık 200-1400 m yükseltili, derin vadilerden oluşan bir topoğrafya ile karakterize edilmektedir. Bu kesimler, Seyhan Nehri ana kollarının birleştiği, drenaj alanlarının genişlediği yerlerdir. Kuzey bölgesi ise, yaklaşık 1400-3600 m yükseltileri arasında yer almaktadır ve en az yağış alan bölgedir. Güney bölgesi, düz ve düze yakın topoğrafyalı, Akdeniz ikliminin hüküm sürdüğü ovalık alanları temsil etmektedir. Bu bölge, yaklaşık 0-200 m yükseltileri arasında yer almaktadır. Yağış yükseklikleri esas alındığında, ovalık kesimler, orta bölgeden sonra en fazla yağış alan yerlerdir.

\subsection{Turc Yöntemi Yüzey Akış Sonuçları}

M. Turc yöntemi ile yüzey akış haritaları CBS ortamında ArcGIS yazılımının Map Algebra modülü ile oluşturulmuştur. Eşitlik 4'te verilen $L$ parametresi haritası üretilirken, Yapay Sinir Ağları yöntemi ile Seyhan Havzası için oluşturulan [45] \%50 olasılıklı ortalama sıcaklık $(T \% 50)$ haritasının raster formatı altlık olarak kullanılmıştır. Cokriging yöntemi ile elde edilen $\% 50, \% 80$ ve $\% 90$ olasılıklardaki toplam yağış $(P)$ ve $N Y I ̇$ yöntemi $\% 65, \% 75$ ve \%85 göstergesi olan eşik yağış $(P)$ haritaları $M$. Turc yüzey akış eşitliğinde (Eşitlik 4) ayrı ayrı işleme alınmıştır. Hesaplamalar sonunda; Parajka ve Szolgay [65] tarafından gerçek evapotranspirasyon (ET) olarak da ifade edilen Seyhan Havzası'ndaki M. Turc yöntemi kayıp $(D)$ haritaları elde edilmiştir. Farklı olasılık düzeyleri ve $N Y I$ eşik değerleri için çizilen $P$ ve $D$ haritaları Map Algebra modülü ile birbirinden çıkarılmıştır. Bu işlemler sonucunda, Seyhan Havzası için M. Turc yöntemine göre $Q_{\% 50}$ (Şekil 4a), $Q_{\% 80}$ (Şekil 4b), $Q_{\% 90}$ (Şekil 4c) olasılıkla beklenen yıllık yüzey akış ve $N Y I$ yöntemindeki kuraklık kategorileri için $Q_{N Y I=\% 65}$ (Şekil 4d), $Q_{N Y I=\% 75}\left(\right.$ Şekil 4e), $Q_{N Y I=\% 85}$ (Şekil 4f) eşik yüzey akış haritaları oluşturulmuştur.

Şekil 4'te verilen farklı olasılıklı yıllık toplam yüzey akış ve $N Y I$ yöntemi farklı kuraklık sınıfı eşik yüzey akış haritaları incelendiğinde, topoğrafyanın yüzey akışlar üzerine olan etkisi açıkça görülmektedir. Zira, Şekil 3'te verilen yağış haritaları ve SYM haritası (Şekil 1a) birlikte değerlendirildiğinde, topoğrafya ve yıllık yağış toplamlarının etkisi yüzey akış miktarlarını da orta, kuzey ve güney olarak 3 bölgeye ayırmaktadır. Yağış haritalarına göre, orta bölgeden sonra güney bölgesi en yüksek yağışı almasına rağmen, yüzey akış haritalarında kuzey bölge ile benzer miktarda yüzey akış oluştuğu gözlenmektedir. Güney bölgesindeki yüzey akış miktarlarının, yüksek sıcaklık ve bunun sonucunda meydana gelen yüksek evapotranspirasyon nedeniyle azaldığı tespit edilmiştir (Şekil 4). Orta bölge ise, yüksek yağış ve nispeten düşük sıcaklıklar nedeniyle yüzey akışların yüksek değerlere ulaştığı bölgedir. Farklı olasılıklı yüzey akış ve eşik yüzey akış haritaları arasında en büyük yüzey akışların \%50 olasılıkla beklenen yıllık toplam yüzey akış haritalarında olduğu görülmüştür. Ayrıca, \%50 olasılıkla beklenen yıllık toplam en küçük yüzey akış miktarı 39- 
$100 \mathrm{~mm}$ aralı̆̆ında değişmiş olup, Ulukışla'nın kuzeydoğusunda ve havza mansabında (Tarsus'un güneyinde) gerçekleşmiştir (Şekil 4a). Sonuç olarak, Seyhan Havzası'nda \%50 olasılık düzeyinde, 39 mm'nin altında yüzey akışı beklenmemektedir.

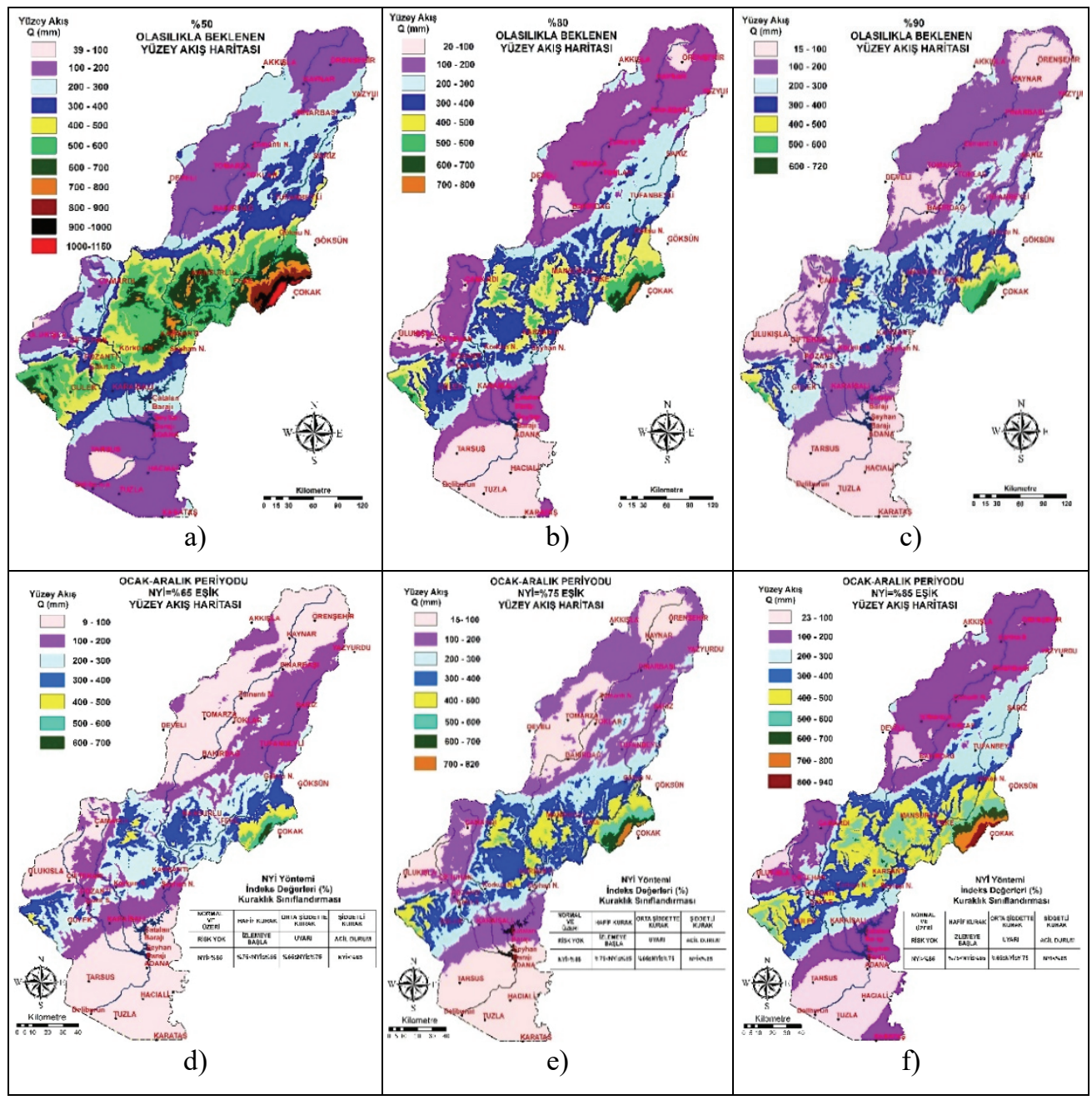

Şekil 4 - Seyhan Havzasi'nda farkl olasilıkl (\%50,\%80, \%90) ylllık toplam yüzey aklş ve NYİ yöntemi farklı kuraklık sinıfları eşik (\%65, \%75, \%85) yüzey akış haritaları

Çizilen yüzey akış haritalarında, yüzey akış miktarlarının alan ile değişimi araştııılmıştır. Kıyaslanabilir sonuçların elde edilebilmesi için "yüzey akış hipsometrik eğrileri" geliştirilmiştir. Şekil 4'te verilen her bir yüzey akış haritası için geliştirilen "yüzey akış hipsometrik eğrileri" yardımılla; akım gözlemi olmayan kuraklığa eğilimli bölgelerde tasarlanacak göletler için havza su veriminin hesaplanmasında kullanılabilecek olasılık düzeyi belirlenmeye çalışılmıştır. Bu amaçla, geliştirilen tüm "yüzey aklş hipsometrik eğrileri" Şekil 5'te verilen kartezyen koordinat grafiği üzerine topluca çizilmiştir. Bu 
eğrilerin davranışları irdelenmek sureti ile kuraklığa eğilimli bölgelerde yüzey akış hesabında kullanılması gereken olasılık düzeyi hakkında bir yaklaşım ortaya konulmaya çalışılmıştır.

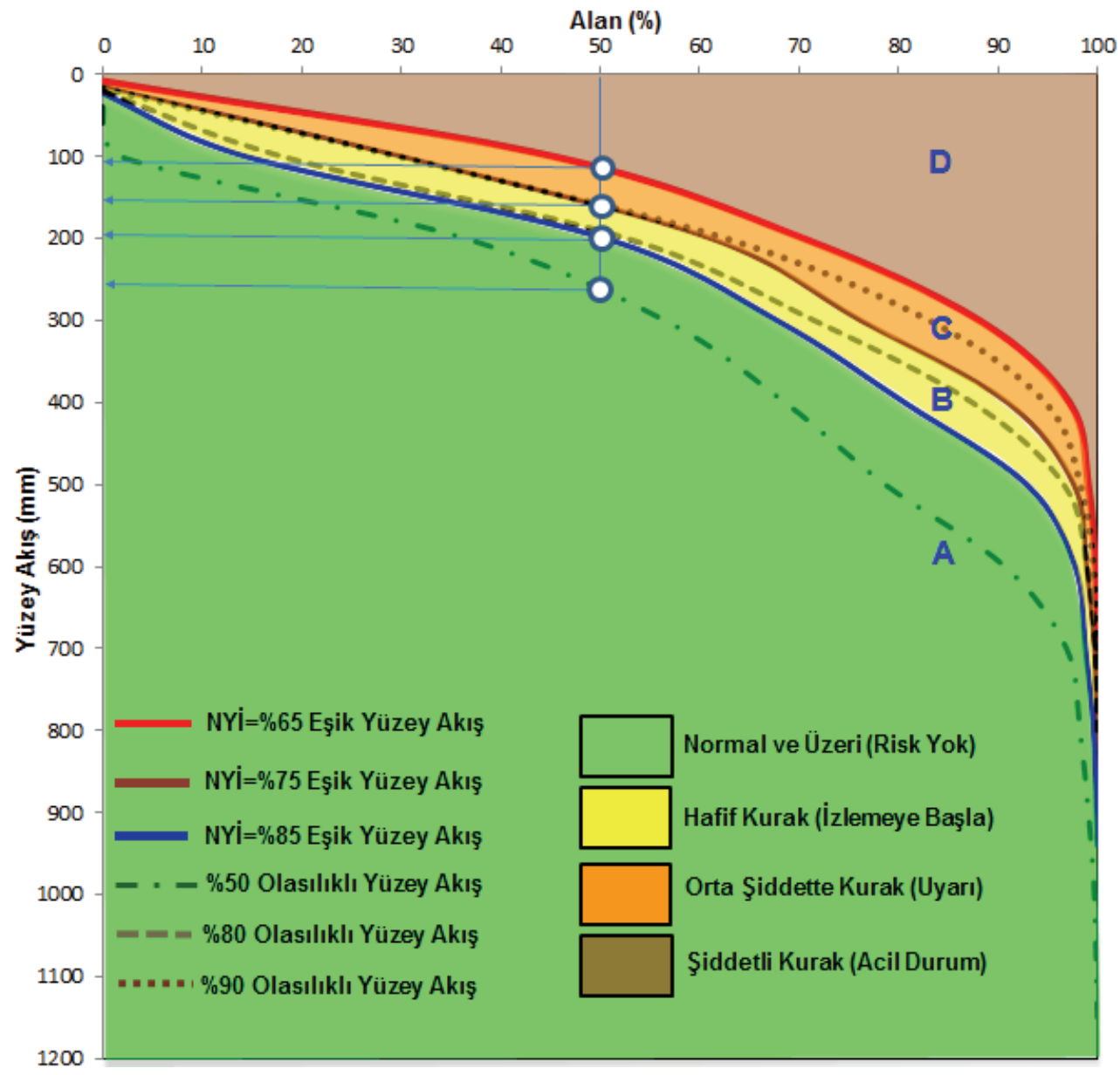

Şekil 5 - Seyhan Havzası 'nda farklı olasılıklı yıllık toplam yüzey akış ve NYİ yöntemi farklı kuraklık sınıfları eşik yüzey akış değerlerine ilişkin hipsometrik ĕgriler

Şekil 5'te görüldüğü üzere, Seyhan Havzası'nda farklı olasılık düzeylerindeki yağışlardan kaynaklanan M. Turc yüzey akış değerlerinin hipsometrik eğrileri ile NYI kuraklık kategorileri için belirlenen eşik yağışların oluşturduğu $M$. Turc yüzey akış değerlerinin hipsometrik eğrileri dikkate değer karakteristik davranışlar göstermektedir. $N Y \dot{I}$ yöntemi kuraklık sınıfları eşik yüzey akış değerleri, her bir kuraklık sınıfını belirgin bir şekilde ayırmıştır (Şekil 5). Bu bağlamda, A bölgesi kuraklık riskinin olmadığ1 "Normal" durumu (NYI>\%85), B bölgesi "Hafif Kurak" durumu $(\% 75<N Y \dot{I} \leq \% 85)$, C bölgesi "Orta Şiddette Kurak" durumu $(\% 65 \leq N Y \dot{I} \leq \% 75)$, D bölgesi "Şiddetli Kurak" durumu $(\mathrm{NY} \dot{\mathrm{I}}<\% 65)$ göstermektedir. D bölgesindeki yüzey akışlar, "Şiddetli Kurak" koşullarda havzada oluşacak 
yüzey akımları göstermektedir. Buna karşın C ve B bölgesindeki yüzey akışlar sırasıyla "Orta Şiddette Kurak" ve "Hafif Kurak" koşullardaki beklenen yüzey akımları göstermektedir. A bölgesindeki yüzey akış değerleri, havzada kuraklık olaylarının hüküm sürmediği "Normal" koşullarda beklenen yüzey akışları tasvir etmektedir. Bu bilgilere göre; $\% 90$ olasılıkla beklenen yıllık toplam yüzey akış miktarları "Orta Şiddette Kurak" dönemlerde oluşabilecek yüzey akış miktarlarını temsil etmektedir. Bu akım değerleri; havzanın \%50'sinde $150 \mathrm{~mm}$ ve daha az olup, bu akışın hipsometrik eğrisi ile $N Y \dot{I}=\% 75$ eşik yüzey akış hipsometrik eğrisi çakışmıştır. Havzanın diğer \%50 'sinde ise akım 150-700 mm arasindadir.

Havzanın tamamında $\% 80$ olasıllkla beklenen yıllık toplam yüzey akış miktarı $N Y \dot{I}=\% 75$ ile $N Y \dot{I}=\% 85$ eşik yüzey akış aralığındadır. Bu akım değerleri; "Hafif Kurak" dönemlerde oluşabilecek yüzey akış miktarlarını temsil etmektedir. Bu olasılık düzeyinde havzanın $\% 50$ 'sinde 195 mm'nin altında yüzey akış beklenmektedir ve havzanın diğer \%50 'sinde ise akım 195-800 mm arasında değişmektedir.

Seyhan Havzası'nın tamamında \%50 olasılıkla beklenen yıllık toplam yüzey akış miktarları "Normal ve Üzeri-Risk Yok" kuraklık sınıfına dahil olmuştur. Bu olasılık düzeyinde beklenen akımlar NYİ yöntemi \%85 kuraklık eşik yüzey akış değerleri üzerinde kalmaktadır. Diğer bir ifadeyle, yağışlı dönemlerde oluşabilecek yüzey akış miktarlarıdır. Elde edilen bu sonuç, gölet tasarımında havza su verimi hesaplamalarında seçilecek olasılık değerinin belirlenmesi bakımından önem arz etmektedir. Bu değerlendirmelerden anlaşlacağı gibi, kuraklık riski altındaki havzalarda, göletlerin tasarımında $\% 50$ olasılıklı yağışların kullanılması sonucunda yüksek oranlarda yüzey akışlar hesaplanmakta; gölet rezervuarları gereğinden fazla kapasitelendirilmektedir. $\mathrm{Bu}$ ise, projelerin gereksiz yere maliyetlerinin artışını beraberinde getirmektedir. Çizelge 5 'te $\% 50$ olasılıkla beklenen akım ve $N Y \dot{I}=\% 85$ eşik akım değerleri arasında havzanın farklı alan yüzdelik dilimlerindeki $N Y \dot{I}=\% 85$ eşik üstü akım değerleri görülmektedir. Burada havzanın \%50'sinde eşik üstü akım değeri $70 \mathrm{~mm}$ altındaki değerler ile temsil edilmiştir. Havzanın tamamına bakıldığında 200 mm'ye kadar eşik üstü akımın oluştuğu görülmüsştür. Ayrıca, havzada alan yüzdesi büyüdükçe "Normal ve Üzeri-Risk Yok" eşik üstü akımların artığı gözlenmiştir.

Çizelge 5 - \%50 olasılıkla beklenen yıllık toplam yüzey akış ve NYI=\%85 eşik yüzey akış hipsometrik ĕgrilerinin karşılaştırılması

\begin{tabular}{lrrrrrrrrrr}
\hline Alan Oranı (\%) & 10 & 20 & 30 & 40 & 50 & 60 & 70 & 80 & 90 & 100 \\
\hline \%50 Olasılıkla Beklenen Akım (mm) & 130 & 150 & 180 & 210 & 265 & 320 & 420 & 510 & 580 & 1150 \\
\hline NYí=\%85 Eşik Akım (mm) & 80 & 120 & 150 & 170 & 195 & 250 & 320 & 390 & 460 & 950 \\
\hline NYí=\%85 Eşik Üstü Akım (mm) & 50 & 30 & 30 & 40 & 70 & 70 & 100 & 120 & 120 & 200 \\
\hline
\end{tabular}

\section{SONUÇ VE ÖNERILER}

Seyhan Havzası'nda akım gözlemi olmayan dereler üzerine inşa edilecek göletlerin hidrolojik tasarımında kullanılan \%80 ve \%90 olasılıkla beklenen akımların NYI kuraklık sınıflamasına göre sırasıyla; "Hafif Kurak ve Orta Şiddette Kurak" dönemlerde oluşabilecek yüzey akışlar olduğu tespit edilmiştir. Ancak, $\% 50$ olasılıkla beklenen y1llık toplam yüzey 
akış miktarlarının ise, "Normal ve Üzeri-Risk Yok" kuraklık sınıfı akım değerlerinin üzerinde olduğu görülmüştür. Kuraklık olaylarının beklenmediği normal koşulların hakim olması durumunda, \%50 olasılıklı yağışların kullanılması proje hidrolojisi ve ekonomisi açısından uygun olacaktır. Sonuç olarak; \%80 ve \%90 olasılıkla beklenen yüzey akış değerleri sırasıyla; "Hafif Kurak" ve "Orta Şiddette Kurak" dönemlerde oluşabilecek akım değerlerini temsil ettiğinden, kuraklık söz konusu olduğunda bu değerlerin kullanılması daha gerçekçi olacaktır. Gölet hazne tasarımlarında, kurak dönemlerin dikkate alınması proje ekonomisine katkı sağlayacaktır. Havzada, \%50 olasılıkla beklenen yıllık toplam yüzey akış miktarları, NYI kuraklık sınıfına göre "Normal ve Üzeri-Risk Yok" kuraklık sınıfı eşik akım değerlerinden daha büyük bulunmuştur. $\mathrm{Bu}$ akımlar, yağışlı dönemlerde oluşabilecek potansiyel yüzey akışları göstermektedir. Oysa, Seyhan Havzası'nda yağış azalması ve kuraklık riski olduğu birçok bilimsel çalışma sonucunda bulgu olarak açıklanmıştır [32-41]. Bu sonuçlara göre; Seyhan Havzası'nda tarımsal ve hayvan içme suyu gölet tasarımlarında $\% 50$ olasılıkla beklenen yıllık toplam yüzey akış miktarları ile gövde tasarımının yapılmaması gerekmektedir. Havzanın potansiyel kuraklık riski dikkate alınmalı, tasarımlarda havza su verimleri $\% 80$ ve $\% 90$ olasılıkla beklenen yüzey akış miktarlarına göre hesaplanmalıdır. Böylelikle gölet gövde yükseklikleri küçüleceğinden maliyetlerde büyük azalmalar elde edilebilecektir.

\section{Kaynaklar}

[1] ICID., Irrigated Agriculture Development Under Drought and Water Scarcity, International Commission on Irrigation and Drainage, 150 p, India, 2017.

[2] Alcamo, J., Henrichs, T., Rösch, T., World Water in 2025, Global Modeling and Scenario Analysis for The World Commission on Water for The $21{ }^{\text {st }}$ Century, Center for Environmental Systems Research, University of Kassel, 2000.

[3] UN., Report of the World Summit on Sustainable Development, United Nations, 26 August-4 September, Johannesburg, South Africa, 2002.

[4] FAO., Coping with Water Scarcity-Challenge of The Twenty-First Century, World Water Day, 29 p, Rome, 2007.

[5] Vogel, S., An Analysis of Water Management Strategies in Drought Prone Areas: A Comparison of Water Management Techniques in California, Chile, and Australia, Masters Project Submitted in Partial Fulfillment of The Requirements for The Masters of Environmental Management Degree in The Nicholas School of The Environment of Duke University,USA, 2018.

[6 ] DSİ., Ormancılık ve Su Şurası, Orman ve Su İşleri Bakanlığı, Devlet Su İşleri, Su Kaynaklarının Geliştirilmesi Çalışma Grubu Raporu, 21-23 Mart, Ankara, 2013.

[7] Kılıç, N., Su Kaynaklarının Yetersizliği Düşündürüyor, Ar-Ge Sektörel Bülten, İzmir Ticaret Odas1, Ekim, 2006.

[8] İMO., Su Hakkı Raporları, İnşaat Mühendisleri Odası, Türkiye Mühendislik Haberleri, 2009/2, Ankara, 2009. 
[9] IWR., National Study of Water Management During Drought, The Report to The U.S. Congress. U.S. Army Corps of Engineers Water Resources Support Center Institute for Water Resources, 94-NDS-12, USA, 1995.

[10] CC., Climate Change and Drought June 2018, Climate Council, Factsheet, Australia, 2018.

[11] Andreadis, K.M., Clark, E.A., Wood, A.W., Hamlet, A.F., Lettenmaier, D.P., Twentieth-Century Drought in the Conterminous United States. American Meteorological Society, Volume:6, Pages; 985-1001, USA, 2005.

[12] Mix, K., Groeger, A.W., Lopes, V.L., Impacts of Dam Construction on Streamflows During Drought Periods in The Upper Colorado River Basin, Texas. Lakes and Reservoirs: Research and Management, 21: 329-337, 2016.

[13] Engindeniz, S., Öztürk, G., Türkiye'de İklim Değişikliğine Karşı Tarım Sektöründe Alınması Gereken Önlemler, Türkiye 9. Tarım Ekonomisi Kongresi, 22-24 Eylül 2010, Şanliurfa, 2.Cilt, s.956-963, 2010.

[14] Lindoso, D.P., Eiro, F., Bursztyn, M., Rodrigues-Filho, S., Nasuti, S., Harvesting Water for Living with Drought: Insights from the Brazilian Human Coexistence with SemiAridity Approach Towards Achieving the Sustainable Development Goals. Sustainability 2018, 10, 622; doi:10.3390/su1003062, 2018.

[15] Fayrap, A., Erzurum İlinde Yapılan Sulama Amaçlı Göletlerin Durumu Yeterlilikleri ve Sorunları Üzerine Bir Araştırma. Atatürk Üniversitesi Ziraat Fakültesi Dergisi, 25 (2): 145-158, 1994.

[16] Bancy, M.M., Malesu, M., Oduor, A., Promoting Rainwater Harvesting Eastern and Southern Africa, the Relma Experience. World Agroforestry, Centre Working Paper 24, Kenya, 2006.

[17] Subagyono, K., Pawitan H., Water Harvesting Techniques for Sustainable Water Resources Management in Catchments Area. Proceedings of International Workshop on Integrated Watershed Management for Sustainable Water Use in a Humid Tropical Region, JSPS-DGHE Joint Research Project, Tsukuba, 2008.

[18] Keskiner, A.D., Farklı Olasılıklı Yağış ve Sıcaklıkların CBS Ortamında Haritalanmasında Uygun Yöntem Belirlenmesi ve M.Turc Yüzey Akış Haritasının Geliştirilmesi: Seyhan Havzası Örneği, Yüksek Lisans Tezi, Çukurova Üniversitesi, 2008.

[19] Alberta (2015). Small Earth Fill Dams, Alberta Agriculture and Forestry, Practical Information for Alberta's Agriculture Industry, Revised September 2015, Agdex 716 (A20), Canada, 2015.

[20] Özlü, H., Kuraklık ve su yönetimi, İklim Değişimi ve Su Ekonomisi Paneli G.Ü. Bilim ve Teknoloji Stratejileri Araştırma ve Geliştirme Merkezi, 17 Mayıs, Ankara, 2007.

[21] OSİB., Ulusal Kuraklık Yönetimi Strateji Belgesi ve Eylem Planı 2017-2023, Orman ve Su İşleri Bakanlığı, Ankara, 2017. 
[22] Mendicino, G., Senatore, A., Versace, P., Water Resources Management in Agriculture under Drought and Water Shortage Conditions: A Case Study in Southern Italy. European Water, 23/24:41-56, 2008.

[23] Kasap, R., Gölet Temel Gövdelerinin Projelendirilmesi, KHGMY, Ankara, 1998.

[24] Özer, Z., Su Yapılarının Projelendirilmesinde Hidrolojik ve Hidrolik Esaslar, Tarım Orman ve Köyişleri Bakanlığı, Köy Hizmetleri Genel Müdürlüğü, Ankara, 1990.

[25] Vanlı, M., Göletlerde Su Temini Çalışmaları, T. C. Bayındırlık ve İskan Bakanlığı, Devlet Su İşleri Genel Müdürlüğü, Hidrometri ve Taşkın Hidrolojisi Semineri, 3-4 Eylül, İstanbul, 1990.

[26] Dalgün, N., Çanakkale Bayramiç Hacıbekirler Sulama Göleti Mühendislik Hidrolojisi Proje Raporu, Köy Hizmetleri Genel Müdürlüğü Yayınları (KHGMY), Ankara, 1998.

[27] Türkeş, M., Akgündüz, A.S., Demirörs, Z., Palmer Kuraklık İndisi’ne Göre İç Anadolu Bölgesi'nin Konya Bölümündeki Kurak Dönemler ve Kuraklık Şiddeti. Coğrafi Bilimler Dergisi, 7 (2), 129-144, 2009.

[28] Bulut, B., Yılmaz, M.T., Türkiye'deki 2007 ve 2013 Yılı Kuraklıklarının NOAH Hidrolojik Modeli İle İncelenmesi. İMO Teknik Dergi, 27 (134): 7619-7634, 2016.

[29] Önöz, B., Oğuz, B., İstanbul Su Temini Sistemi ve Kuraklık Analizi. İMO Teknik Dergi, 7 (31), 1083-1090, 1996.

[30] Kadığlu, M., Kuraklıkda Kiriz Yönetimininden Risk Yönetimine Geçmeliyiz. Afet Zararlarını Azaltmanın İlkeleri, JICA Türkiye Ofisi Yayınları No: 2, Ankara, 2008.

[31] Kapluhan, E., Türkiye'de Kuraklık ve Kuraklığın Tarıma Etkisi. Marmara Coğrafya Dergisi, 27: 487-510, 2013.

[32] Ekmekçi, M., Jeolojik Geçmişten Günümüze İklim Değişiklikleri: Küresel İklim Değişimi ve Türkiye, TMMOB İklim Değişimi Sempozyumu, 13-14 Mart, 2008, s. 726, Ankara, 2008.

[33] Tezcan, L., Ekmekçi, M., Atilla, Ö., Gürkan, D., Yalçınkaya, O., Otgonbayar, N., Saylu, M.E., Donma, S., Yılmazer, D., Akyatan, A., Pelen, N., Topaloğlu, F., İrvem, A., Seyhan Nehri Havzasında Tarım Güvenliği İçin Su Kaynakları Sistemlerinin İklim Değişikliğine Karşı Duyarlılıklarının Araştırılması, ICCAP Projesi Türk Grubu Sonuç Raporları, s. 1-24, Kyoto, 2007.

[34] Kanber, R., Kapur, B., Ünlü, M., Tekin, S., Koç D.L., İklim Değişiminin Tarımsal Üretim Sistemleri Üzerine Etkisinin Değerlendirilmesine Yönelik Yeni Bir Yaklaşım: ICCAP Projesi, TMMOB 2. Su Politikalar1 Kongresi, 83-94, 2003.

[35] Fujihara, Y., Tanaka, K., Nagano, T., Watanabe, T., Kojiri T., Assessing The Impact of Climate Change on The Water Resources of The Seyhan River Basin, Turkey, In: Proceedings of the International Congress River Basin Management, Vol. 1, Antalya, Turkey, pp. 453-463, 2007.

[36] Topçu, E., Seçkin, N., Drought Analysis of the Seyhan Basin by Using Standardized Precipitation Index (SPI) and L-moments. Journal of Agricultural Sciences, 22: 196$215,2016$. 
[37] Keskiner, A.D., Çetin, M., Uçan, M., Şimşek, M., Coğrafi Bilgi Sistemleri Ortamında Standardize Yağış İndeksi Yöntemiyle Olasılıklı Meteorolojik Kuraklık Analizi: Seyhan Havzası Örneği. Çukurova Tarım Gıda Bilimleri Dergisi, 31 (2): 79-90, 2016.

[38] Tuncok, İ. K., Drought Planning and Management: Experience in the Seyhan River Basin, Turkey. IWA Publishing, Water Policy, 18 (S2): 177-209, 2016.

[39] Çetin, M., Keskiner, A.D., Nagano, T., Kubota, J., Coğrafi Bilgi Sistemleri Ortamında Olasılıklı Bölgesel Meteorolojik Kuraklık Analizi: Seyhan Havzası Örneği.13. Ulusal Kültürteknik Kongresi, Akdeniz Üniversitesi, Ziraat Fakültesi, Tarımsal Yapılar ve Sulama Bölümü, 12-15 Nisan, Antalya, Bildiriler Kitabı: 332-339, 2016.

[40] Gül, G.O., Kuzucu, A., Analysis of Drought Severity in Seyhan River Basin. European Water, 60: 211-217, 2017.

[41] Gümüş, V., Algin, H.M., Meteorological and Hydrological Drought Analysis of The Seyhan-Ceyhan River Basins, Turkey. Meteorological Applications, 24: 62-73, 2017.

[42] DSİ., Göl-Su Projesi. Devlet Su İşleri, http://www.dsi.gov.tr/projeler/gol-su-projesi, Erişim tarihi: 11.112018

[43] Çetin, M., Topaloğlu, F., Yücel, A., Tülücü, K., Yağış Kayıtları ve Bazı Önemli İstatistiklerin Jeoistatistik Yöntemle İncelenmesi: Seyhan Havzası Örneği, II. Ulusal Hidroloji Kongresi, sayfa 75-82, İstanbul, 1998.

[44] Esri., Spatial Analysis. http://www.esri.com, Erişim Tarihi: 11.11.2018.

[45] Keskiner, A.D., İbrikçi, T., Çetin, M., Yapay Sinir Ağlarıyla Coğrafi Bilgi Sistemi Ortamında Olasılıklı Sıcaklık Tahmini ve Karşılaştırılması. Tarım Bilimleri Dergisi, 17 :241- 252, 2011.

[46] Ryan, B.F., Cryer, J., Minitab Handbook, Fifth Edition, Regression and Correlation, In: 313-349, Belmont, California, 2005.

[47] BestFit., Users's Guide @rrsk Risk Analysis and Simulation Add-In for Microsoft巴Excel, http://www.palisade.com/risk/, Erişim tarihi: 11.11.2018.

[48] Tülücü, K., KT-310 Uygulamalı Hidroloji, Çukurova Üniversitesi Ziraat Fakültesi Yayınları: 138 Ders Kitabı:A-143, 315 s., Adana, 2002.

[49] Chow, V.T., Maidment, D.R., Mays, L.W., Applied Hydrology, McGraw-Hill, Inc., Civil Engineering Series, 572 p, New York, 1988.

[50] Şen, Z., Applied Drought, Modeling, Prediction and Mitigation, Elsevier: 9780128024225,484 p., Amsterdam, Netherlands, 2015.

[51] Willeke G., Hosking J.R.M., Wallis J.R., Guttman N.B., The National Drought Atlas, Institute for Water Resources Report, 94-NDS-4, U.S. Army Corps of Engineers, 1994.

[52] Çetin, M., Özcan, H., Tülücü, K., Aşağı Seyhan Ovası IV.Merhale Proje Alanında Toprak ve Taban Suyuna İlişkin Bazı Fiziksel ve Kimyasal Özelliklerin Yersel Değişimlerinin Jeoistatistik Yöntemle Araştırılması, Araştırma Projesi Sonuç Raporu, Adana, 2001. 
[53] Hayes, M.J., Drought Indices. Western Water Assessment, Feature Article From Intermountain West Climate Summary, Colorado, USA, 2007.

[54] MGM., Meteoroloji Genel Müdürlüğü. https://www.mgm.gov.tr/veridegerlendirme/kuraklikanalizi.aspx?d=yontemsinif\#sfB ,Erişim tarihi: 11.112018.

[55] Englund, E., Sparks, A., GEOEAS User's Guide, EPA, Las Vegas, NV, 1991.

[56] Çıtakoğlu, H., Çetin, M., Çobaner, M., Haktanır, T., Mevsimsel Yağışların Jeoistatistiksel Yöntemle Modellenmesi ve Gözlemi Olmayan Noktalarda Tahmin Edilmesi. İMO Teknik Dergi, 28 (136): 7725-7745, 2017.

[57] Taylan, E.D., Damçayırı, D., Isparta Bölgesi Yağış Değerlerinin IDW ve Kriging Enterpolasyon Yöntemleri ile Tahmini. İMO Teknik Dergi, 27 (133): 7551-7559, 2016.

[58] Eriş, E., Ağıralioğlu, N., Ölçümleri Az Olan Kıyı Bölgelerinde Yağışın Yerel Dağılımının Belirlenmesi: Doğu Karadeniz Bölgesi. İMO Teknik Dergi, 28 (136): 7685-7702, 2017.

[59] Çetin, M., Jeoistatistiksel Yöntem İle Nokta ve Alansal Yağışların Saptanması ve Stokastik Olarak Modellenmesi Örnek Havza Uygulamaları, Doktora Tezi, Çukurova Üniversitesi, 1996.

[60] Atlı, A., Yer Altı Suyu (YAS) Kirlenme Potansiyelinin, CBS Tabanlı Drastic Modeli Kullanılarak Belirlenmesi ve Erzin Ovası Yas Hassasiyet Haritalarının Geliştirilmesi, Doktora Tezi, Çukurova Üniversitesi, 2010.

[61] Goovaerts, P., Ordinary Cokriging Revisted. Mathematical Geology, International Association for Mathematical Geology 30 (1): 21-42, 1988.

[62] Türkyılmaz, Y., Rezervuar Hidrolojisi Seminer Notları, T.C Başbakanlık, Köy Hizmetleri Genel Müdürlüğü, Ankara, 1996.

[63] Vivoni, E.R., Benedetto, F.D., Grimaldi, S., Eltahir, E.A.B., Hypsometric Control on Surface and Subsurface Runoff. Water Resources Research, Vol. 44, W12502, doi:10.1029/2008wr006931, 2008.

[64] Eriş, E., Aksoy, H., Önöz, B., Çetin, M., Yüce, M.İ., Selek, B., Aksu, H., Burgan, H.İ., Eşit, M., Yıldırım, I., Karakuş, E.Ü., Frequency Analysis of Low Flows in Intermittent and Non-Intermittent Rivers from Hydrological Basins in Turkey. Water Supply 1 February 2019; 19 (1): 30-39, doi: https://doi.org/10.2166/ws.2018.051

[65] Parajka, J., Szolgay, J., Grid-Based Mapping of Long-Term Mean Annual Potential and Actual Evapotranspiration in Slovakia. Hydrology, Water Resources and Ecology in HeadWaters (Proceedings of the Headwater '98 Conference Held in Meran/ Merano, from 20 to 23 April, Italy), 1998. 